\title{
Mikrokontroler - narzędzie bardzo przydatne w pracach badawczych
}

\begin{abstract}
W artykule przedstawiono charakterystykę mikrokontrolerów 8-bitowych z rodziny AVR. W szczególności położono nacisk na to, aby pokazać ogromne możliwości tych układów w aspekcie wykorzystania ich w codziennym funkcjonowaniu laboratorium badawczego. W pierwszej części dokonano ogólnej charakterystyki mikrokontrolerów oraz podzespołów współpracujących z tymi układami. Następnie przedstawiono sposób praktycznego wykorzystania mikrokontrolera na przykładzie hipotetycznego stanowiska badawczego.
\end{abstract}

Słowa kluczowe: mikrokontroler, stanowisko badawcze, czujnik, pomiar, programowanie, język C.

\section{Microcontroller - a very useful tool in research}

This article presents the characteristics of 8-bit microcontrollers from the AVR family. In particular, emphasis was placed on showing the great potential of these systems in terms of their use in the everyday functioning of a research laboratory. In the first part, the general characteristics of the microcontrollers and the subassemblies cooperating with these systems, were made. An example of the practical use of a microcontroller is shown on the example of a hypothetical test stand.

Key words: microcontroller, test stand, sensor, measurement, programming, language C.

\section{Wprowadzenie}

Powszechna automatyzacja i chęć ciągłej poprawy jakości życia sprawiają, że elektronika cyfrowa nieubłaganie wypiera z naszego otoczenia elektronikę analogową. Już niemal każde z otaczających nas urządzeń elektronicznych zawiera w sobie układ mikroprocesorowy, z czego często nawet nie zdajemy sobie sprawy. Nie inaczej jest również w laboratoriach badawczych. Stosowane jeszcze niedawno analogowe mierniki wskazówkowe zastąpione zostały wysokospecjalizowanymi przyrządami cyfrowymi. Podobna zmiana objęła również całe stanowiska badawcze. Układ sterowania, który do tej pory zajmował sporo miejsca, czasami wręcz całe szafy, teraz mieści się w małej „czarnej skrzynce”, a obsługa stanowiska sprowadza się do kilku kliknięć myszką komputera. Istnieje jednak istotna wada tego postępu cywilizacyjnego - koszt zakupu wspomnianej „czarnej skrzynki”.
Kwota, którą trzeba zapłacić za specjalnie wykonane na zamówienie urządzenie dedykowane, może osiągnąć poziom skutecznie zniechęcający niejednego zainteresowanego. Jest to jednak zrozumiałe, gdyż stworzenie takiego urządzenia wymaga niezbędnej wiedzy z zakresu elektroniki, automatyki, informatyki i innych dziedzin pokrewnych. Nic więc dziwnego, że konstruktorzy odpowiednio cenią swoją pracę. Autor artykułu, który miał przyjemność po trosze zgłębić tę wiedzę, twierdzi jednak, że nie zawsze musimy być skazani na korzystanie z cudzych rozwiązań. Umysł analityczny, odrobina samozaparcia i przyswojenie niewielkiej ilości niezbędnej wiedzy z zakresu elektroniki pozwolą konstruować proste, lecz w pełni funkcjonalne urządzenia elektroniczne. Przedstawiony w tym artykule praktyczny przykład może być tego dowodem.

\section{Układ mikroprocesorowy}

Każde urządzenie zawierające w sobie mikrokontroler należy rozpatrywać z dwóch punktów widzenia:
- sprzętu (hardware), czyli części związanej z dziedziną elektroniki, 
- oprogramowania (software), czyli części związanej z dziedziną informatyki.

Elementy te powinny ze sobą ściśle współpracować, tworząc $w$ efekcie działające urządzenie o określonych cechach użytkowych [5]. Elementem pośredniczącym pomiędzy tymi dwiema płaszczyznami i jednocześnie najważniejszą częścią układu jest mikrokontroler, będący zarządcą i strażnikiem całego urządzenia. Aby mógł jednak pełnić tę funkcję, należy go odpowiednio zaprogramować, tj. zlecić mu wykonywanie jasno określonego zadania (algorytmu), które pozwoli osiągnąć założony cel. Działanie mikrokontrolera nierozerwalnie związane jest z jego otoczeniem, czyli częścią sprzętową. Do por- tów wejściowych mikrokontrolera może dopływać mnóstwo różnych informacji, które wedle uznania programisty mogą w odpowiedni sposób wpływać na działanie algorytmu. Źródłem takich sygnałów może być na przykład klawiatura lub jakikolwiek inny interfejs pozwalający użytkownikowi na komunikowanie się z urządzeniem. Największą jednak grupę elementów wejściowych stanowią różnego rodzaju czujniki i sensory monitorujące wybrane parametry procesowe. Mikrokontroler analizuje otrzymane informacje wejściowe, a następnie zgodnie z zaimplementowanym algorytmem wpływa na działanie podłączonych do swoich portów wyjściowych elementów wykonawczych lub podejmuje inne niezbędne czynności.

\section{Mikrokontroler}

Czym właściwie jest mikrokontroler? Wiele osób mylnie utożsamia go z mikroprocesorem spotykanym w komputerach PC. Mikroprocesor znajdujący się w komputerze do swojej pracy potrzebuje układów peryferyjnych, takich jak: dysk twardy, pamięć RAM, karta graficzna, oprzyrządowanie płyty głównej itd. Dopiero te wszystkie elementy umieszczone w jednej obudowie tworzą funkcjonalną całość w postaci komputera. Wyobraźmy sobie, że mikrokontroler jest właśnie takim komputerem, zamkniętym w małej obudowie w postaci układu scalonego [1]. Porównanie takie jest oczywiście daleko idącym przybli- żeniem. W rzeczywistości mikrokontroler jest układem znacznie prostszym i mniej wydajnym niż komputer. Nie ma to jednak większego znaczenia, gdyż jego zastosowanie jest zupełnie inne. Moce obliczeniowe oferowane przez mikrokontrolery są wystarczające do sprostania niemal każdemu, nawet najbardziej wymagającemu zadaniu stawianemu w układach automatyki, sterowania czy w każdym innym zastosowaniu. Mikrokontroler nie posiada systemu operacyjnego i od razu po włączeniu zasilania przystępuje do realizacji algorytmu, który może być zaimplementowany w postaci programu komputerowego.

\section{Możliwości mikrokontrolerów}

Obecnie na rynku dostępna jest niezliczona liczba tych układów. Różnią się one od siebie wielkością, mocą obliczeniową, wbudowanymi układami peryferyjnymi oraz oczywiście ceną. Ceny układów wahają się od kilku do kilkudziesięciu złotych. W artykule tym opisana została bardzo szeroka rodzina mikrokontrolerów 8-bitowych AVR produkcji Atmel. Tego typu mikrokontrolery mogą być taktowane częstotliwością nawet $32 \mathrm{MHz}$. W rzeczywistości tak duża moc oblicze- niowa potrzebna jest tylko w najbardziej wymagających zadaniach. Bardziej interesujące z punktu widzenia projektanta układu elektronicznego jest to, jakimi układami peryferyjnymi dysponuje mikrokontroler. W tablicy 1 przedstawiono dostępne w układach AVR wewnętrzne moduły oraz możliwości ich zastosowania [3].

Przedstawione w tablicy 1 opisy wewnętrznych układów pokazują mnogość zastosowań mikrokontrolerów. O prawdziwym

Tablica 1. Peryferia i układy wewnętrzne mikrokontrolerów AVR

\begin{tabular}{|l|l|}
\hline \multicolumn{1}{|c|}{ Wewnętrzny układ } & \multicolumn{1}{c|}{ Możliwości zastosowania } \\
\hline Jednostka arytmetyczno-logiczna & - wykonywanie nawet najbardziej skomplikowanych operacji matematycznych \\
\hline Pamięć flash (pamięć programu) & - pamięć nieulotna, miejsce na program (algorytm) \\
\hline Pamięć RAM & - pamięć ulotna \\
\hline Pamięć EEPROM & - pamięć nieulotna, przechowywanie danych roboczych nawet po zaniku zasilania \\
\hline Porty (nóżki mikrokontrolera) & - dwustronna komunikacja z otoczeniem mikrokontrolera \\
\hline Przetwornik analogowo-cyfrowy & $\begin{array}{l}\text { - bardzo dokładny pomiar napięcia, prądu, rezystancji, mocy i wielu innych parametrów } \\
\text { - rejestracja dźwięku }\end{array}$ \\
\hline Przetwornik cyfrowo-analogowy & $\begin{array}{l}\text { - generowanie dźwięku } \\
\text { - generowanie dowolnego sygnału napięciowego }\end{array}$ \\
\hline Komparator analogowy & - porównywanie dwóch wartości napięć \\
\hline
\end{tabular}


cd. Tablica 1

\begin{tabular}{|c|c|}
\hline Wewnętrzny układ & Możliwości zastosowania \\
\hline Timer/licznik & $\begin{array}{l}\text { - zliczanie różnego rodzaju zdarzeń wewnętrznych lub zewnętrznych } \\
\text { - licznik impulsów } \\
\text { - generator impulsów } \\
\text { - generator sygnałów (np. PWM) } \\
\text { - pomiar częstotliwości } \\
\text { - odmierzanie czasu }\end{array}$ \\
\hline Moduł UART & $\begin{array}{l}\text { - dwukierunkowa transmisja danych w standardzie RS-232 } \\
\text { - dwukierunkowa transmisja danych w standardzie RS-485 }\end{array}$ \\
\hline Moduł SPI & - dwukierunkowa komunikacja z układami w otoczeniu mikrokontrolera \\
\hline Moduł TWI $\left(\mathrm{I}^{2} \mathrm{C}\right)$ & - dwukierunkowa komunikacja z układami w otoczeniu mikrokontrolera \\
\hline System przerwań & - zwiększenie możliwości funkcjonalnych, poprawa elastyczności pracy \\
\hline Watchdog & - czuwa nad poprawnością pracy mikrokontrolera \\
\hline
\end{tabular}

spektrum możliwości można przekonać się jednak dopiero po przeanalizowaniu tablicy 2, prezentującej przykłady układów, z którymi mogą one współpracować. Układy te dołączane są do mikrokontrolera za pomocą jego portów. Do komunikacji pomiędzy nimi można zastosować któryś z wbudowanych sprzętowo w mikrokontroler modułów transmisji lub poprzez dołączenie odpowiedniej biblioteki można emu- lować niemal każdy inny rodzaj wymiany danych. Na uwagę zasługuje również sposób podłączenia układów wykonawczych. Moc, którą można pobrać z portu mikrokontrolera, jest niewielka, wystarczy do zasilenia jedynie niewielkich odbiorników, np. diody LED. Zastosowanie jednak elementów pośredniczących pozwoli na sterowanie każdym odbiornikiem, nawet tym o największej mocy.

Tablica 2. Układy, z którymi może współpracować mikrokontroler AVR

\begin{tabular}{|c|c|}
\hline Zewnętrzny układ & Charakterystyka \\
\hline \multicolumn{2}{|r|}{ UKŁADY WEJŚCIOWE } \\
\hline $\begin{array}{l}\text { Czujnik temperatury (np. Pt100, } \\
\text { termoelement, czujnik cyfrowy) }\end{array}$ & \multirow{17}{*}{$\begin{array}{l}\text { Działanie większości czujników polega na przekształceniu nieelektrycznej wartości zmierzonej } \\
\text { na sygnał elektryczny. Najczęściej spotykane sygnały wyjściowe czujników to [7]: } \\
\text { - zwarcie - rozwarcie styków } \\
\text { - sygnał prądowy } 4 \div 20 \mathrm{~mA} \\
\text { - sygnał napięciowy } 0 \div 10 \mathrm{~V} \\
\text { - rezystancja } \\
\text { - pojemność } \\
\text { - częstotliwość } \\
\text { - transmisja RS-232 } \\
\text { - transmisja RS-485 } \\
\text { - transmisja 1-wire } \\
\text { - transmisja SPI } \\
\text { - transmisja TWI }\left(\mathrm{I}^{2} \mathrm{C}\right) \\
\text { - inne... }\end{array}$} \\
\hline Czujnik wilgotności, punktu rosy & \\
\hline Czujnik ciśnienia, barometr & \\
\hline $\begin{array}{l}\text { Czujnik gazu (np. metanu, } \\
\text { wodoru, czadu) }\end{array}$ & \\
\hline Czujnik alkoholu & \\
\hline Czujnik pH & \\
\hline Czujnik ruchu & \\
\hline Czujnik przepływu & \\
\hline Czujnik poziomu & \\
\hline Czujnik przyspieszenia, żyroskop & \\
\hline Czujnik odległości & \\
\hline Czujnik wibracji & \\
\hline Czujnik nacisku & \\
\hline Czujnik dźwięku & \\
\hline Czujnik natężenia i barwy światła & \\
\hline Czujnik koloru & \\
\hline Czujnik pola magnetycznego & \\
\hline Zegar czasu rzeczywistego & Bardzo dokładny pomiar czasu \\
\hline
\end{tabular}


cd. Tablica 2

\begin{tabular}{|c|c|}
\hline Zewnętrzny układ & Charakterystyka \\
\hline \multicolumn{2}{|r|}{ UKŁADY WYKONAWCZE } \\
\hline Silnik DC & Może osiągać bardzo duże obroty, dostępne różne moce silników \\
\hline Silnik krokowy & $\begin{array}{l}\text { Bardzo duży moment obrotowy, możliwość wykonania precyzyjnego obrotu o dowolny kąt, pra- } \\
\text { ca krokowa }\end{array}$ \\
\hline Serwomechanizm & Bardzo duży moment obrotowy, możliwość wykonania precyzyjnego obrotu o dowolny kąt \\
\hline Elektrozawór & Otwieranie i zamykanie przepływu gazu lub cieczy \\
\hline $\begin{array}{l}\text { Kontaktron, przekaźnik, tranzystor } \\
\text { MOSFET, optotriak, transoptor }\end{array}$ & Układy pośredniczące w sterowaniu urządzeniami dużej mocy \\
\hline Głośnik, buzzer & Generowanie dźwięku, pojedynczych sygnałów dźwiękowych \\
\hline Dioda laserowa & Źródło bardzo mocnego promieniowania spójnego \\
\hline \multicolumn{2}{|r|}{ INTERFEJSY UŻYTKOWNIKA } \\
\hline Klawiatura, przycisk, switch & $\begin{array}{l}\text { Umożliwiają wydawanie mikrokontrolerowi pojedynczych komend lub wprowadzanie całych } \\
\text { ciągów znaków }\end{array}$ \\
\hline Dioda LED & Sygnalizacja stanów, zdarzeń \\
\hline $\begin{array}{l}\text { Wyświetlacz ciekłokrystaliczny } \\
\text { tekstowy }\end{array}$ & $\begin{array}{l}\text { Umożliwia wyświetlanie tekstu i liczb. Dostępne w różnych rozmiarach, maksymalnie } 4 \times 40 \\
\text { znaków }\end{array}$ \\
\hline $\begin{array}{l}\text { Wyświetlacz ciekłokrystaliczny } \\
\text { graficzny }\end{array}$ & $\begin{array}{l}\text { Umożliwia wyświetlanie grafiki, wykresów, tekstu i liczb. Dostępne w różnych rozmiarach, mak- } \\
\text { symalnie } 240 \times 128 \text { pikseli }\end{array}$ \\
\hline \multicolumn{2}{|r|}{ MODUŁY TRANSMISJI DANYCH } \\
\hline Moduł Bluetooth & $\begin{array}{l}\text { Umożliwia bezprzewodową komunikację mikrokontrolera z drugim urządzeniem, np. kompute- } \\
\text { rem lub smartfonem (zasięg do kilkudziesięciu metrów) }\end{array}$ \\
\hline Dioda IR & $\begin{array}{l}\text { Umożliwia bezprzewodową komunikację mikrokontrolera z drugim urządzeniem (zasięg trans- } \\
\text { misji ograniczony zasięgiem światła podczerwonego) }\end{array}$ \\
\hline $\begin{array}{l}\text { Moduł Ethernet } \\
\text { Moduł Wi-Fi }\end{array}$ & $\begin{array}{l}\text { Umożliwia komunikację za pośrednictwem sieci internetowej z serwerem lub dowolnym innym } \\
\text { urządzeniem podłączonym do sieci }\end{array}$ \\
\hline Moduł GSM & $\begin{array}{l}\text { Umożliwia komunikację bezprzewodową za pośrednictwem sieci komórkowej, np. ze smartfo- } \\
\text { nem lub dowolnym urządzeniem wyposażonym w moduł GSM }\end{array}$ \\
\hline Moduł radiowy $433 \mathrm{MHz}$ & $\begin{array}{l}\text { Umożliwia komunikację bezprzewodową za pośrednictwem fal radiowych z dowolnym urządze- } \\
\text { niem wyposażonym w moduł radiowy } 433 \mathrm{MHz}\end{array}$ \\
\hline Karta SD & Zapis danych roboczych na zewnętrznej przenośnej pamięci \\
\hline
\end{tabular}

\section{Środowisko i język programowania}

W kwestii programowania do wyboru mamy kilka możliwości. W przypadku mikrokontrolerów AVR najlepszym wyborem, według autora, jest skorzystanie $\mathrm{z}$ dostarczanego przez producenta tych układów darmowego środowiska do programowania AVR Studio. Co do języka programowania tu też jest kilka możliwości. Najlepszym wyborem będzie jednak język C. Jest to bardzo uniwersalny i intuicyjny język programowania, który doskonale sprawdza się również przy pracy z mikrokontrolerami. Niewątpliwą zaletą języka C, która ułatwia pracę po- czątkującym programistom, jest to, że w sieci WWW można znaleźć wiele przykładowych programów. Analizując je, dużo łatwiej zrozumieć ideę działania mikrokontrolerów. Dodatkowo w księgarniach dostępnych jest sporo książek poruszających tematykę programowania mikrokontrolerów w tym języku (np. [2, 3]). Autorzy książek, widząc coraz większe zainteresowanie mikrokontrolerami, prześcigają się, aby w jak najbardziej przystępny sposób opisać tę mimo wszystko niełatwą tematykę. Przejdźmy zatem do przykładu praktycznego.

\section{Przykład praktyczny}

Rozważmy przykład zastosowania mikrokontrolera w charakterze hipotetycznego sterownika stanowiska badawczego do sprawdzania odporności gazomierzy miechowych na długotrwałe oddziaływanie wysokiej temperatury. Badanie na 
tym stanowisku polegać ma na umieszczeniu na okres dwóch miesięcy gazomierza wewnątrz izolowanej termicznie szafy, w której za pomocą zainstalowanej wewnątrz grzałki utrzymywana będzie temperatura na poziomie $60^{\circ} \mathrm{C}\left( \pm 3^{\circ} \mathrm{C}\right)$. Wymagania odnośnie do pracy stanowiska badawczego są następujące:

- w pełni autonomiczna praca,

- utrzymywanie temperatury w szafie grzewczej na poziomie niewykraczającym poza dopuszczalne granice,

- sterowanie grzałką o mocy $500 \mathrm{~W}$,

- pomiar temperatury wewnątrz szafy grzewczej,

- pomiar wilgotności względnej wewnątrz szafy grzewczej,

- pomiar ciśnienia atmosferycznego,

- zliczanie impulsów LF z gazomierza,

- pomiar czasu,

- sygnalizacja dźwiękowa w sytuacji, gdy temperatura w szafie jest zbyt wysoka,

- wyświetlanie na zintegrowanym wyświetlaczu aktualnie zmierzonych parametrów,

- bezprzewodowa transmisja danych do komputera PC.

Wyżej wymienionym zadaniom z powodzeniem sprosta mikrokontroler Atmega32. Układem pośredniczącym w sterowaniu grzałką będzie przekaźnik z wyjściem zwiernym o dopuszczalnym obciążeniu prądowym 5 A. Jako czujnik warunków środowiskowych w szafie zastosowano cyfrowy sen- sor SHT75 firmy Sensirion, charakteryzujący się stosunkowo dobrą dokładnością pomiarową (niepewność pomiaru temperatury: $\pm 0,3^{\circ} \mathrm{C}$, a wilgotności $\left.\pm 2,0 \% \mathrm{RH}\right)$. Do pomiaru ciśnienia atmosferycznego wybrano czujnik BMP180 firmy Bosch (niepewność pomiaru: $\pm 0,12 \mathrm{hPa}$ ). Pomiar czasu realizowany będzie za pomocą układu DS3231 produkcji Dallas Semiconductor (niepewność pomiaru czasu: $\pm 2 \mathrm{ppm}$ ). Wszystkie trzy wymienione powyżej układy posiadają interfejs komunikacyjny $\mathrm{I}^{2} \mathrm{C}$. Źródłem impulsów w gazomierzu jest zwarciowy kontaktron magnetyczny, co umożliwia podłączenie go bezpośrednio do portu mikrokontrolera. Zliczanie impulsów zostanie zrealizowane programowo. Generatorem sygnału alarmowego będzie niewielki buzzer piezoelektryczny, który również może zostać podłączony bezpośrednio do portu mikrokontrolera. Aktualne wyniki pomiarów prezentowane będą na tekstowym wyświetlaczu LCD o rozdzielczości 4 × 20 znaków. Bezprzewodowa transmisja danych do komputera PC zrealizowana zostanie w standardzie Bluetooth za pomocą dołączonego modułu HC-06. Na rysunku 1 przedstawiono poglądowy schemat zaprojektowanego sterownika. Aby nie utrudniać analizy schematu, nie zawarto na nim kilku drobnych, ale niezbędnych do poprawnej pracy układu elementów (kondensatory filtrujące, rezystory podciągające linie sygnałowe, rezystory ograniczające prąd, potencjometr regulacji kontrastu wyświetlacza).

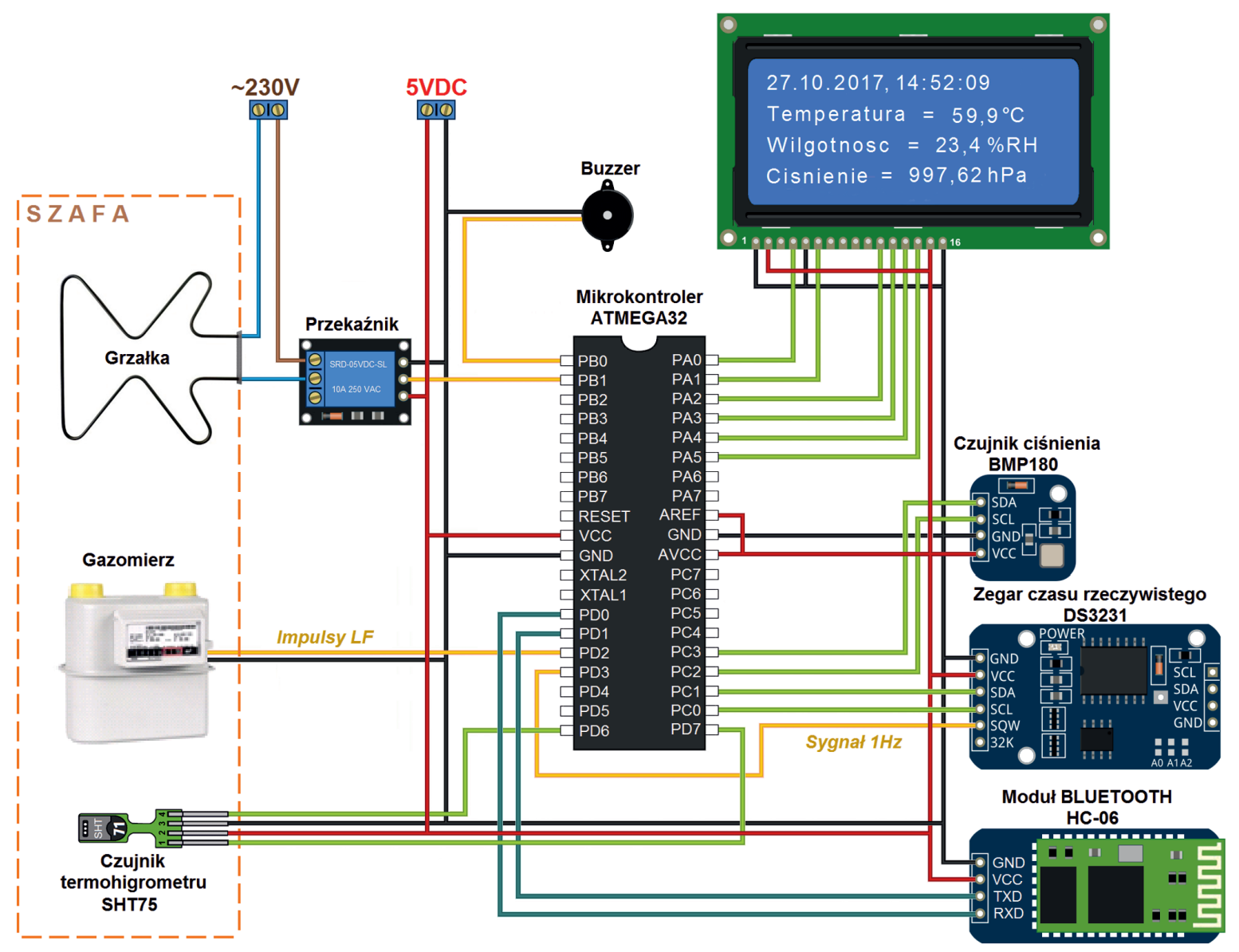

Rys. 1. Schemat ideowy sterownika szafy grzewczej 


\author{
\#include <avr/io.h> \\ \#include <avr/interrupt.h> \\ \#include "HD44780.h" \\ \#include "usart.h" \\ \#include "DS3231.h" \\ \#include "SHT75.h" \\ \#include "BMP180.h"
}

TDATETIME datetime;
float temperatura;
float wilgotnosc;
float cisnienie;

// dołączenie pliku nagłówkowego z definicjami rejestrów i bitów mikrokontrolera

// dołączenie pliku nagłówkowego obsługi przerwań

// dołączenie do programu biblioteki wyświetlacza LCD

// dołączenie do programu bibliotekiz funkcjami transmisji RS232

// dołączenie do programu biblioteki układu DS3231

// dołączenie do programu biblioteki czujnika temperatury i wilgotności SHT75

// dołączenie do programu biblioteki czujnika ciśnienia BMP180

// stworzenie w pamięci struktury przechowującej datę i czas

// stworzenie zmiennej przechowującej wartość temperatury

// stworzenie zmiennej przechowującej wartość wilgotności względnej

// stworzenie zmiennej przechowującej wartość ciśnienia atmosferycznego

// stworzenie zmiennej przechowującej liczbę zliczonych impulsów

// program główny

// inicjalizacja wyświetlacza LCD

// inicjalizacja interfejsu TWI

// inicjalizacja interfejsu UART

// inicjalizacja układu DS3231

// inicjalizacja czujnika SHT75

// inicjalizacja czujnika BMP180

// przygotowanie nóżki O w porcie B do współpracy z grzałką

// przygotowanie nóżki 1 w porcie B do współpracy z buzzerem

DDRB $\mid=(1<<P B 1)$

MCUCR |= (1<<ISC01)|(1<<ISC00); // konfiguracja wejścia współpracującego z wyjściem impulsowym gazomierza

GICR I= $(1<<I N T 0)$;

// cd. konfiguracji wejścia współpracującego z wyjściem impulsowym gazomierza

GIFR $\mid=(1<<\mid N T 0)$;

// cd. konfiguracji wejścia współpracującego z wyjściem impulsowym gazomierza

sei ();

// globalne zezwolenie na przerwania

while(1)

// główna pętla programu

\{

if ( GIFR \& (1<<INTF1))

// sprawdzanie, czy układ DS3231 przysłał informację o upłynięciu kolejnej sekundy \{

Get_Date_Time();

LCD_GoTo(0,0);

Display_Date_Time();

Get_temp_SHT75(temperatura);

LCD_GoTo $(0,1)$;

LCD_Write_Text (,Temperatura $=$ ")

LCD_Write_Float(temperatura);

LCD_Write_Data(223);

LCD_Write_Text("C");

Get_hum_SHT75(wilgotnosc);

LCD_GoTo(0, 2);

LCD_Write_Text $($,Wilgotnosc $="$ )

LCD_Write_Float(wilgotnosc);

LCD_Write_Text("\%RH");

Get_press_BMP180(cisnienie);

LCD_GoTo(0,3);

LCD_Write_Text(,Cisnienie $=$ ")

LCD_Write_Float(cisnienie);

LCD Write Text("hPa");
// odczytanie z układu DS3231 aktualnej daty i godziny

// ustaw kursor wyświetlacza LCD w pozycji: kolumna 0, wiersz 0

// wyświetlenie na wyświetlaczu LCD aktualnej daty i godziny

// odczytanie z czujnika SHT75 aktualnie zmierzonej temperatury

// ustaw kursor wyświetlacza LCD w pozycji: kolumna 0, wiersz 1

// wyświetlenie na wyświetlaczu LCD tekstu „Temperatura = "

// wyświetlenie na wyświetlaczu LCD wartości temperatury

// wyświetlenie na wyświetlaczu LCD symbolu ","

// wyświetlenie na wyświetlaczu LCD symbolu „C"

// odczytanie z czujnika SHT75 aktualnie zmierzonej wilgotności względnej

// ustaw kursor wyświetlacza LCD w pozycji: kolumna 0, wiersz 2

// wyświetlenie na wyświetlaczu LCD tekstu „Wilgotnosc = "

// wyświetlenie na wyświetlaczu LCD wartości wilgotności względnej

// wyświetlenie na wyświetlaczu LCD jednostki „\%RH”

// odczytanie z czujnika BMP180 aktualnie zmierzonego ciśnienia

// ustaw kursor wyświetlacza LCD w pozycji: kolumna 0, wiersz 3

// wyświetlenie na wyświetlaczu LCD tekstu „Cisnienie = "

// wyświetlenie na wyświetlaczu LCD wartości ciśnienia

// wvświetlenie na wvświetlaczu LCD iednostki „hPa”

Rys. 2. Kod programu sterownika szafy grzewczej 


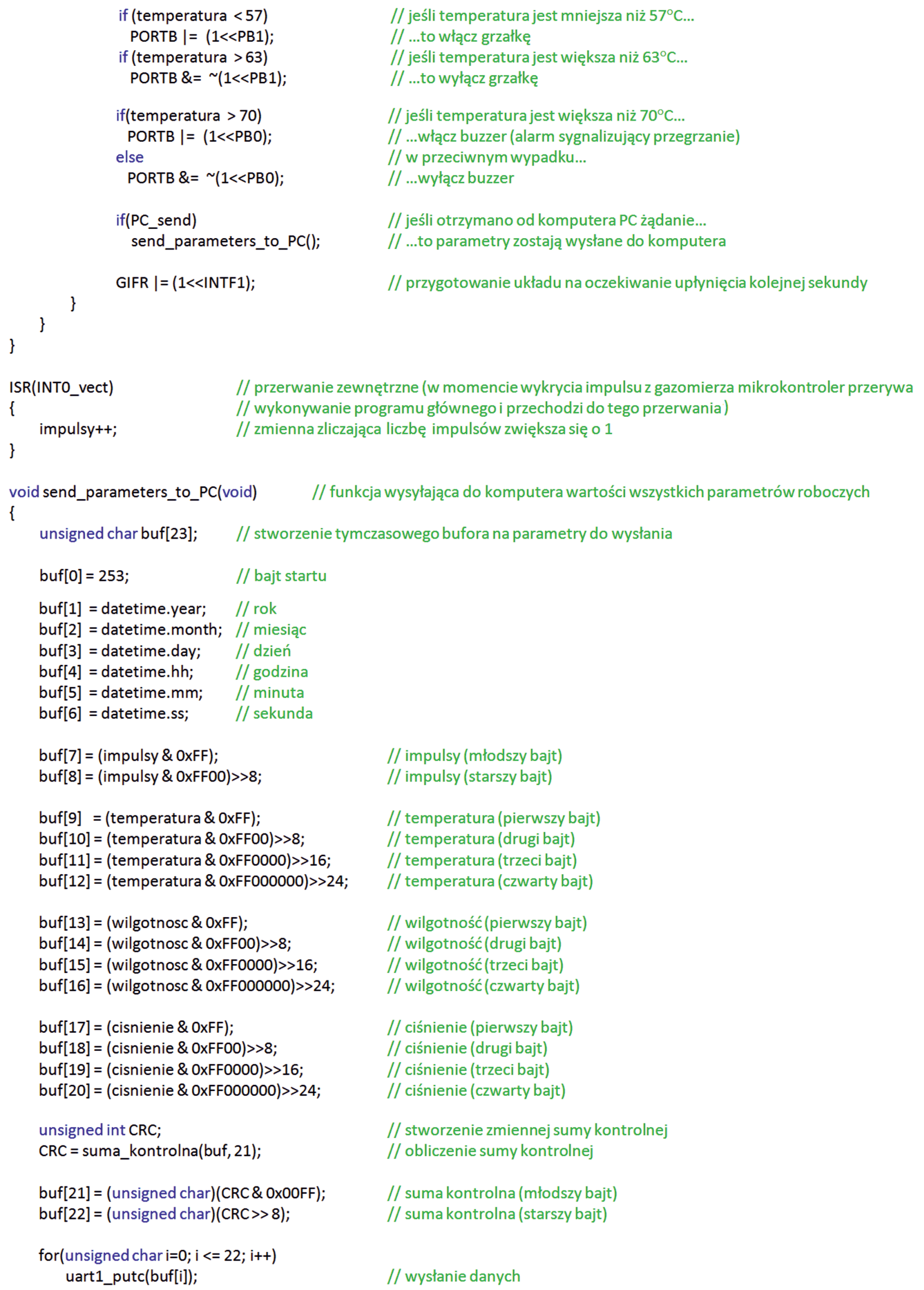

// jeśli temperatura jest mniejsza niż $57^{\circ} \mathrm{C}$...

...to włącz grzałke

// jeśli temperatura jest większa niż $63^{\circ} \mathrm{C}$.

..włącz buzzer (alarm sygnalizujący przegrzanie)

// w przeciwnym wypadku..

// jeśli otrzymano od komputera PC żądanie...

// ...to parametry zostają wysłane do komputera

// przygotowanie układu na oczekiwanie upłynięcia kolejnej sekundy

(3)

Rys. 2 cd. Kod programu sterownika szafy grzewczej 
Układ przedstawiony na rysunku 1 można fizycznie wykonać na kilka sposobów. Najprostszym z nich jest wykorzystanie tzw. płytki uniwersalnej lub stykowej. Rozwiązania te są jednak mało estetyczne. Autor poleca skorzystanie z programu KiCad. Choć jest to oprogramowanie typu open source, umożliwia ono jednak zaprojektowanie w pełni profesjonalnej płytki drukowanej. W tablicy 3 zawarto zestawienie kosztów wszystkich części niezbędnych do samodzielnego wykonania opisanego przykładu. Podane ceny są cenami uśrednionymi na podstawie ofert kilku popularnych sklepów internetowych. Na rysunku 2 przedstawiono najprostszy kod programu, który może realizować założone cele. Do każdej linii kodu dołączono komentarz wyjaśniający znaczenie poszczególnych fragmentów programu.

Tablica 3. Zestawienie kosztów wykonania opisanego stanowiska badawczego

\begin{tabular}{|l|c|}
\hline \multicolumn{1}{|c|}{ Element } & Cena, koszt wykonania \\
\hline Mikrokontroler Atmega32 & $10 \mathrm{zl}$ \\
\hline Czujnik termohigrometru SHT75 & $110 \mathrm{zł}$ \\
\hline Czujnik ciśnienia BMP180 & $14 \mathrm{zł}$ \\
\hline Zegar czasu rzeczywistego DS3231 & $20 \mathrm{zł}$ \\
\hline Moduł Bluetooth HC-06 & $30 \mathrm{zł}$ \\
\hline Wyświetlacz LCD 4 $\times 20$ znaków & $2 \mathrm{zł}$ \\
\hline Przekaźnik 5 A & $1 \mathrm{zł}$ \\
\hline Buzzer 5 V & 2 zł \\
\hline Elementy drobne & $15 \mathrm{zl}$ \\
\hline Zasilacz +5VDC & $10 \mathrm{zł}$ \\
\hline Płytka drukowana (wykonana „domowym sposobem”) & $80 \mathrm{zł}$ \\
\hline Grzałka & $\mathbf{3 0 0 ~ z l}$ \\
\hline LĄCZNIE: & bezcenne! \\
\hline $\begin{array}{l}\text { Możliwość zaprojektowania działania układu ściśle } \\
\text { według naszych potrzeb }\end{array}$ & \\
\hline
\end{tabular}

\section{Podsumowanie}

Celem, który przyświecał autorowi podczas pisania tego artykułu, było zainteresowanie tematyką mikrokontrolerów osób niemających do tej pory styczności z tymi układami. W szczególności autor chciał przedstawić ogromne możliwości tych układów w aspekcie zastosowania ich w codziennym funkcjonowaniu laboratorium badawczego. W artykule zaprezentowany został praktyczny sposób wykorzystania mikrokontrolera na przykładzie prostego stanowiska badawczego. Choć przedstawione stanowisko jest nieskomplikowane, to jednak trudno byłoby znaleźć na rynku gotowe rozwiązanie, które zrealizowałoby założone cele. Przy nieco bardziej złożonych procedurach badawczych niezbędne byłoby zle- cenie wykonania stanowiska badawczego osobie lub firmie specjalizującej się w tego typu projektach. Obie możliwości, choć dobre, wiążą się jednak ze znacznymi kosztami. Przedstawiony przykład pokazuje, że każdy może podjąć wyzwanie tworzenia prostych układów opartych na mikrokontrolerach. Dobre opanowanie tej sztuki z pewnością przyniesie wymierne korzyści wszędzie tam, gdzie zachodzi konieczność wykonywania żmudnych, czasochłonnych, powtarzalnych i dokładnych pomiarów, jak również innych czynności. Przykłady innych stanowisk badawczych, na których doskonale sprawdziłby się mikrokontroler, opisano w artykułach: $[4,6,8]$.

Prosimy cytować jako: Nafta-Gaz 2018, nr 5, s. 391-398, DOI: 10.18668/NG.2018.05.07

Artykuł nadesłano do Redakcji 9.01.2018 r. Zatwierdzono do druku 20.03.2018 r.

\section{Literatura}

[1] Borkowski P.: AVR i ARM7. Programowanie mikrokontrolerów dla każdego. Helion 2010.

[2] Francuz T.: Język C dla mikrokontrolerów AVR od podstaw do zaawansowanych aplikacji. Helion 2011.

[3] Kardaś M.: Mikrokontrolery AVR. Język C-podstawy programowania. Atnel 2013.

[4] Kuśnierczyk J.: Badania przepuszczalności rdzeni wiertniczych z użyciem różnych płynów złożowych. Nafta-Gaz 2015, $\mathrm{nr} 2$, s. 87-96.

[5] Pawluczuk A.: Sztuka programowania mikrokontrolerów AVR. BTC, Warszawa 2006.

[6] Szuflita S.: Badania laboratoryjne oddziaływania gazów kwaśnych na skatę zbiornikowa w procesach sekwestracji $\mathrm{CO}_{2}$. Nafta-Gaz 2016, nr 7, s. 520-527, DOI: 10.18668/NG.2016.07.04.
[7] Szymczyk P., Szymczyk M., Gajer M.: Cyfrowe czujniki do pomiarów wielkości nieelektrycznych $w$ automatyce. Pomiary Automatyka Robotyka 2010, nr 4, s. 18-21.

[8] Warnecki M.: Badania procesów wypierania metanu przy udziale sekwestracji $\mathrm{CO}_{2}$. Nafta-Gaz 2015, nr 3, s. 159-166.



Mgr inż. Jacek MATUSIK

Starszy specjalista inżynieryjno-techniczny;

Zastępca kierownika Laboratorium Wzorcującego, Zakład Metrologii Przepływów

Instytut Nafty i Gazu - Państwowy Instytut Badawczy ul. Lubicz 25 A, 31-503 Kraków

E-mail: jacek.matusik@inig.pl 